\title{
STUDY OF SOCIAL-SPATIAL EXCLUSION AND IDENTIFYING ITS FACTORS BETWEEN ENQELAB STREET AND COLLEGE CROSSROAD IN TEHRAN
}

\author{
Mahnaz Alimohammadi \\ MSc of urban development planning, Faculty of Arts and Architecture, Islamic Azad University Central \\ Tehran Branch \\ Dr. Atusa Modiri \\ Member of Scientific Board, Faculty of Arts and Architecture, Islamic Azad University Central Tehran \\ Branch
}

\begin{abstract}
Despite the fact that public spaces should be accessible for everyone, sometimes some of these spaces by the boundaries created by the owners or social groups, are only accessible for particular groups of society. Such boundaries in addition to reduction in the level of spaces' communication, is a limiting factor in the entry and presence of different society classes in urban spaces; while increasing the presence and interaction of citizens with each other and interaction with space improves urban life. It can be said that most boundaries on public spaces with private and public ownership or symbolic ownership are all negative consequences of ownership and lead to social-spatial exclusion of other segments of society. This article aims to explain examples of social-spatial exclusion on Enqelab St. in Tehran. We used exploratory-qualitative approach in this research. By using survey and documents we collected data and finally analyzed the data through mapping, and provided a conclusion about influencing factors on socialspatial exclusion on the street, and thus provided some suggestions for reducing social-spatial exclusion in Enqelab Street.
\end{abstract}

Keywords: social exclusion, ownership, urban access, Enqelab Street, College Crossroad.

\section{INTRODUCTION}

Lin Tadman defines the concept of social exclusion as: Social exclusion refers to the complex processes that some groups or communities are systematically blocked from rights, opportunities and resources (e.g., housing, employment, health care, civic engagement, democratic participation and due process) that are normally available to all people; or the right to access these issues is denied. The result of this deprivation prevents individuals and groups to fully take part in their community's economic, political and social life (Todman, 2012). Therefore, the way boundaries influence urban spaces, urban space supervision and access in increasing or decreasing social exclusion can be investigated.

By examining different studies it can be seen that social exclusion is often studied with a sociological approach. A gap is seen between social exclusion and urban science; the gap can be seen more in studies inside the country. Thus many papers and theses carried out to reduce social exclusion, however, we can see not much works are done in regard to social-spatial exclusion. Due to the importance of the route between Enqelab St. and College Crossroad and the need to identify influencing factors in reducing social-spatial exclusion in this street and explaining examples of exclusion and approaches to control and decrease it and also to create a balance between exclusion and inclusion, the main research question is how and by which means, one can reduce social-spatial exclusion in the route between Enqelab Street and College Crossroad? 


\section{RESEARCH OBJECTIVE}

Enqelab Street in Tehran, as the name (Enqelab means Revolution in Persian language) indicates, always have direct and immediate relationship with the deepest social practices. Besides, this street had been played social and cultural role in Tehran by adopting cultural and artistic activities such as City Theater of Tehran and many other uses of this kind. As north of the old city of Tehran, was a place for recreational events and this can be seen in similar activities in Enqelab Street in Tehran. However, cultural and physical changes occurred in the street is not in harmony of its particular character and has been changed beyond the understanding of social identity. The relationship between the city and its citizens through social access is discrete today and this will lead to even more unfair exploitation of the street as an urban space. Consider urban space as space of citizens' daily lives. The space where different groups of people of different ages and different needs and demands use it for different reasons. People with a very different political, social and historical background and a space that allows people's gathering. Since the Enqelab Street is free for everyone and can be used on a daily basis, different people are present there and pass the route for shopping, appointments, and so on. The street is full of private and public ownership of public spaces. The dominant activities are cultural, educational and recreational activities that seem to be accessible only to certain groups of society.

In this study, a view toward these spaces with urban identity is considered which along with the development, focuses on access in mutual relationships and moves toward social access and body congruence. This view is fundamental definition of urban planning, and its main purpose is to improve the quality of urban spaces to improve the quality of life. The major effort in this paper is to provide a proper and logical answer to the mention question through applying an approach to "prevent the social exclusion of urban space" is. In fact, what is forgotten and abandoned in changes in Enqelab Street and many other squares and streets as spaces of an old city will be placed at the center of attention. In fact, the main purpose of this paper is redefining the basic elements of social-qualified urban spaces - including performance components, aesthetics and environmental components -, in order to strengthen the collective life in these spaces and create a sense of place. In fact it is a background view of the development which has a balanced approach to development and access. So it observes the recent changes and on the other hand, transfers old concepts from epoch to epoch. The questions we try to answer in this research include:

1. What are the factors influencing the social-spatial exclusion?

2. What are examples of social-spatial exclusion on Enqelab Street to College Crossroad?

3. How and by which means, one can reduce social-spatial exclusion in the route from Enqelab Street to College Crossroad?

\section{THEORETICAL FRAMEWORK PRINCIPLES AND PRINCIPLES social exclusion}

Social exclusion refers to the complex processes that some groups or communities are systematically blocked from rights, opportunities and resources (e.g., housing, employment, health care, civic engagement, democratic participation and due process) that are normally available to all people; or the right to access these issues is denied. Although theorists have studied social exclusion in different aspects and examined it in different aspects from economy to participation in life and political rights, but all of them agree on two features which are the process nature of social exclusion and lack of access to facilities and resources.

Numerous definitions of social exclusion are as follows:

- $\quad$ Social exclusion occurs where different factors combine to trap individuals and areas in a spiral of disadvantage. (DSS, 1999, p 23) 
Social exclusion is a process, which causes individuals or groups, who are geographically resident in a society, not to participate in the normal activities of citizens in that society. (Scottish Executive, ND)

The processes by which individuals and their communities become polarized, socially differentiated and unequal. (ESRC, 2004)

- $\quad$ The dynamic process of being shut out from any of the social, economic, political and cultural systems which determine the social integration of a person in society. (Walker and Walker, 1997, p 8)

A lack or denial of access to the kinds of social relations, social customs and activities in which the great majority of people in British society engage. In current usage, social exclusion is often regarded as a 'process' rather than a 'state' and this helps in being constructively precise in deciding its relationship to poverty. (Gordon et al, 2000, p 73)

- $\quad$ An individual is socially excluded if (a) he or she is geographically resident in a society but (b) for reasons beyond his or her control, he or she cannot participate in the normal activities of citizens in that society, and (c) he or she would like to so participate. (Burchardt et al, 2002, pp 30, 32)

- $\quad$ Inadequate social participation, lack of social integration and lack of power. (Room, 1995)

Social exclusion is a broader concept than poverty, encompassing not only low material means but the inability to participate effectively in economic, social, political and cultural life and in some characterizations alienation and distance from mainstream society. (Duffy, 1995) (Quoted by Levitas \& Etal, 2007).

In her book "patterns of social exclusion," Hilary Silver says "Europeans conceive of social exclusion as distinct from income poverty. Poverty is a distributional outcome, whereas exclusion is a relational process of declining participation, solidarity, and access. For some, exclusion is a broader term encompassing poverty; for others, it is a cause or a consequence of poverty. The two may even be unrelated" (Hilary Silver, S.M. Miller).

The term exclusion is widely used associated with privately owned spaces which have public use, such as a properties. (Hirsch \& Et al, 2000, p. 78)

Dividing social life into public and private sections means to draw boundaries around some the material and spatial areas and eliminating the rest areas. In this way, exclusion is an act of formal and practical method to control access to places, activities, resources and information. (Madanipour: 2010, p. 76).

\section{Accessibility}

The key element in any discussion on the public domain is accessibility. Since the public domain must be accessible to everyone by its definition. Some environments -intended or unintended- have little access to certain sectors of society. Preventing (deprivation) often endorse or strengthen the implication of "exclusivity" or "security". This is essentially a kind of power through space control and access (Carmona: 2004, 113). Accessibility and deprivation be discussed in terms of public domain management (which includes preventing or excluding undesirable/disturbing social behavior). Managers and owners of semi-public space have different motivations for reviewing the activities; including their responsibility for maintenance, their commitment to what is about to happen in that space and their concern for marketability. Exclusion of specified activities/behaviors can be even a responsibility in control or management (Carmona: 2004, 113).

Some of the strategies demand the exclusion of particular individuals or social groups, rather than specific behaviors. A right of private ownership is access prevention and protection. Otherwise, if a particular order is not created, one cannot easily and legally be excluded from the public space. However, the public 
domain is the space that is available to the public but has been in private ownership, for example, places with public distribution (e.g. through density bonuses, or direct monetary subsidies) while people think of them as accessible (Carmona: 2010, 114). Bendji, with explanation of such spaces, observes that since the public are pleasant as supporters of shops and restaurants or as traders or customers, access to and use of space has been left as a bonus rather than the right. The individuals or undesirable groups that their mere presence creates an anxiety in others could be deprived to improve the welfare and security of others and for the benefit. This type of access control is usually risk averted and tends to exclude many than a few. With a positive view, such strategies are based on the shape, on the recognition of groups or individuals who are supposedly more inclined to disobey the desired behavior. Therefore, one can be focused there. With a negative view, this leads to stereotypes and separation (Karamvna: 2010, 115). Access varies in accordance with day, time, season (Rezvani 2014, 1). According to Ben Vegas, public space has four features of accessibility as: i) physical access, ii) social access, iii) access to activities and discussions or intercommunications, iv) access to information.

\section{Boundary}

The boundary between public and private areas is of one objects that we use symbolically to provide identity to certain parts of our lives. The boundary is also important since it is placed between two areas as well, and plays an intermediary role. Since boundary is a line that has been drawn in space to divides the world into two areas, as it may be a reflection of power relations system as well. Boundary is employed by creating barriers to shape behavior, access can be limit and controlled and different groups in society can be brought under management (Madanipour, 2010: 271).

Simmel claims that boundary is not a spatial fact with sociological consequences, but a sociological fact that forms itself spatially. Spatial Boundaries are formed by and reproduced by social action and also impress themselves on ways of thinking. Modes of separating and connecting spaces (borders, boundaries paths bridges) give objective form to subjective understanding of space and then serve to conduct the subject in space. (Simmel quoted from Tonkiss: 2009, 47).

\section{Ownership}

Ownership is a direct form of space control. Ownership can be real and symbolic. Real ownership is when a space is legally owned by an individual, group or company. Symbolic ownership is a more common style that users feel them as part of public places. The results of perceived ownership have positive and negative consequences. When ownership results in the exclusion of people who would like to use a space, access is denied. Ownership can also serve to invite people into a space by communication a sense of caring or responsibility. (Altman \& H.Zube: 165). Public space is also controlled by the rulers and yet public domain is with ambiguity and is used by all members of society. Hence there is confusion about the concept of the public domain because it refers both to the government and the public, i.e. to the whole and the even to its subset, both to generality and to specific categories, both to non-personal relationships and interpersonal relationships, both to tangible concepts and abstract concepts, both to common concepts and to personal concepts; and it refers to levels and types of access, and benefits and variable types (Madanipour, 159: 2008).

\section{METHODOLOGY}

Urban design as an interdisciplinary field reflects different methods of research and studies. The research method in this paper is exploratory. As the name of exploratory indicates, it seeks to explore things that happen and questions them. In exploratory research, many unknown phenomena or relations or their meanings are discovered or explained more clearly. In this paper through exploratory research, we seek to find out the factors that affect the reduction of social-spatial exclusion in public spaces, and find some examples between Enqelab St. to College Crossroad in Tehran, and then provide suggestions for reducing social exclusion on the route from Enqelab St. to College Crossroad. (M. philips \& S. pugh, 2005: 63). 
This article aims to explain examples of social exclusion on Enqelab St. in Tehran and following research questions:

1. What are the factors influencing the social-spatial exclusion?

2. What are examples of social-spatial exclusion on Enqelab Street to College Crossroad?

3. How and by which means, one can reduce social-spatial exclusion in the route from Enqelab Street to College Crossroad?

And for obtaining answer to question 1, we reviewed the research literature and electronic papers and identified the influencing factors, to answer question 2, by understanding studied areas by the studying the documents and direct observation of the space and sometimes in order to verify observations, we conducted interviews (asked Cafes' owners about their customers and what hours they come there?) in accordance with the standards. And then analyzed them in form of maps. Finally, by integrated analysis of standards we obtained the answers to question 2. The required data have been obtained in two ways:

Documents: gathering information through reading, books and magazines (printed documents), Internet resources are valid. These studies are done by attending libraries, centers and affiliated agencies. Data collection is done by primary check-operation and classifications to collect the literature and understanding of the context of the case.

Survey: includes collecting data through observation and interviews for better understanding of the context of the case.

In this paper, we attempted to use semi-structured interview and conversation with interviewees to collect information. The reason for choosing semi-structured interviews was several issues including the social dimension of the issue in which coping with them was not possible during the interview.

Table 1. Criteria and Data Collection Method

\begin{tabular}{|c|c|c|c|c|}
\hline component & criteria & Sub-criteria & codes & $\begin{array}{l}\text { Data collection } \\
\text { method }\end{array}$ \\
\hline \multirow{5}{*}{$\begin{array}{l}\text { Access to } \\
\text { space }\end{array}$} & Visual access & Visual view & Space visibility & Field-Observation \\
\hline & \multirow{2}{*}{ Society access } & Social boundaries & $\begin{array}{l}\text { Social groups } \\
\text { whom made } \\
\text { boundaries }\end{array}$ & $\begin{array}{l}\text { Field-Observation- } \\
\text { Interview }\end{array}$ \\
\hline & & $\begin{array}{l}\text { Symbolic } \\
\text { boundaries }\end{array}$ & Signs and symbols & $\begin{array}{l}\text { Field-Observation- } \\
\text { Interview }\end{array}$ \\
\hline & \multirow{2}{*}{ Physical access } & Physical barriers & & Field-Observation \\
\hline & & edge & Active or Inactive & Field-Observation \\
\hline $\begin{array}{l}\text { Access to } \\
\text { activities }\end{array}$ & $\begin{array}{l}\text { Activity } \\
\text { attraction }\end{array}$ & Activity pattern & $\begin{array}{l}\text { Cultural- } \\
\text { educational, } \\
\text { recreational- }\end{array}$ & $\begin{array}{l}\text { Field-Observation- } \\
\text { Interview }\end{array}$ \\
\hline
\end{tabular}




\begin{tabular}{|c|c|c|l|c}
\hline & & leisure, abnormal & \\
\cline { 3 - 5 } & & $\begin{array}{c}\text { Social groups of } \\
\text { activists }\end{array}$ & $\begin{array}{l}\text { Sex ratio, age, the } \\
\text { time of space } \\
\text { activists }\end{array}$ & $\begin{array}{c}\text { Field-Observation- } \\
\text { Interview }\end{array}$ \\
\hline ownership & $\begin{array}{c}\text { Ownership } \\
\text { type }\end{array}$ & $\begin{array}{c}\text { Real ownership } \\
\text { Symbolic } \\
\text { ownership }\end{array}$ & & $\begin{array}{c}\text { Documents- Field- } \\
\text { Observation- } \\
\text { Interview }\end{array}$ \\
\hline
\end{tabular}

In this qualitative study, we cannot use a specific and unique formula to determine the sample size. Powell believes the simple solution to determine the sample size to continue data collection until the elements of study reach saturation point. The point in which even people no longer add anything to the data or what they present is not in contrast to the collected knowledge (Hariri: 2006, 141). Accordingly, in order to identify spatial exclusion criteria, by 35 interviews, essential elements reached saturation point and replies and responses seemed being repeated. In this paper, after survey and understanding criteria on the range and producing maps, summarized Integrated Analysis was conducted on the range.

\section{CASE STUDY}

Enqelab Street is one important streets in the city of Tehran and is considered as the main street of downtown. Connecting Enqelab Square (24 Esfand) to Imam Hossein Square (Fozieh). Due to the fact that numerous universities and department stores including books and journals stores being located in the route, it is one considered as one of important and busy streets of Tehran. This area is centered between Districts 6 and 11. So that northern blocks are located in the $6^{\text {th }}$ district and southern blocks are located in $11^{\text {th }}$ district. Since 1966, the street was known as the main axes of identity with a few dominant performance of city services such as education, cultural, commercial and amusement. Despite the passing of 20 years since that time and emergence of other services in other parts of town, the context not only maintained its position as a major axis of urban services, but with the construction of City Theater, Vahdat Hall it also increased its importance as an educational and cultural center.

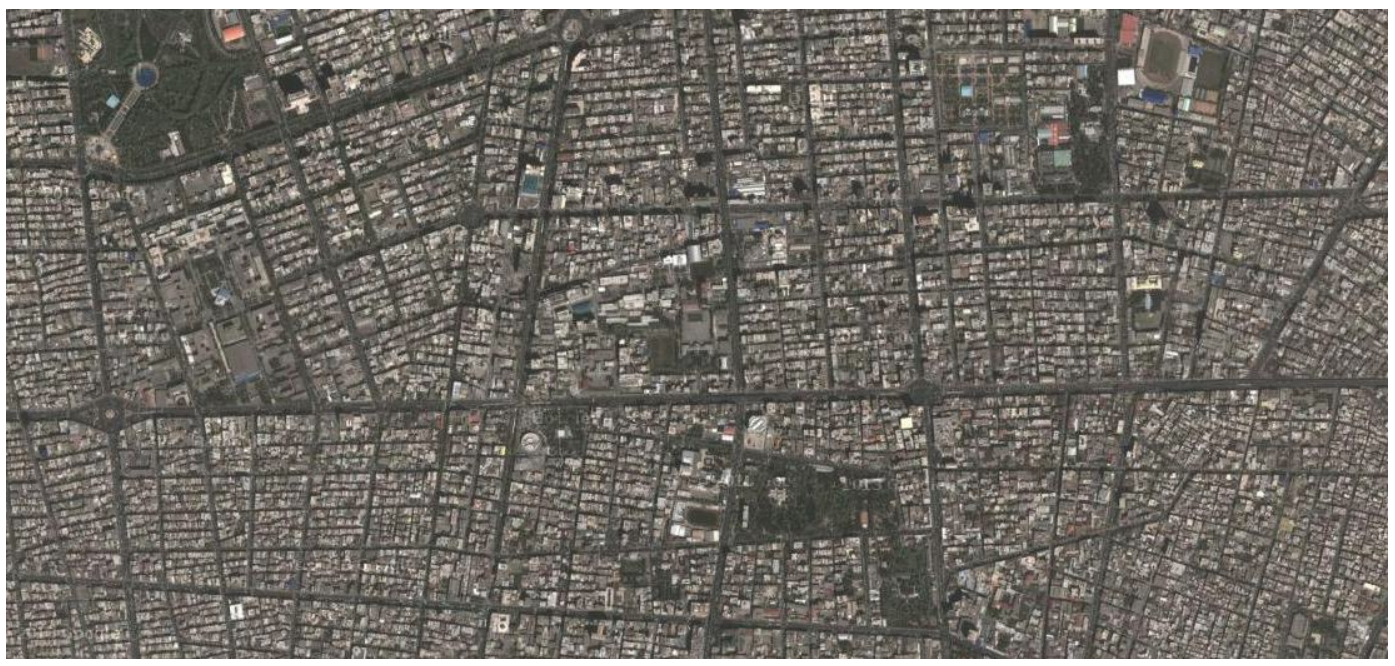


Fig 1. Enqelab Street and neighborhoods

Tehran as Iran's capital since the last two centuries is manifestation and the source of enormous reconstruction. The first transformation occurred from Naser-al-din Shah. But the fundamental steps took place during the reign of Reza Shah. And by urban projects, it attempted to alter the morphology of Tehran urban area. (Madanipour, 61: 2002). During Reza Khan, extensive interventions in the context of old Tehran occurred. City of Tehran in the early reign of Reza Khan (1925) almost was not different from reign of Naseri. With the approval of the first plan of Tehran, "the municipality" the first project under the name of street map of Tehran carried out in 1930. New streets were built. (Buzarjomehri and Khayyam and main thoroughfares became wider.

Demolition of the old Tehran fence began from 1932. In the next years boulevards were replaced instead of the fence: in north, Shahreza Street (currently: Enqelab St.), in east Shahbaz 11 Street (currently: Shahrivar), in south Shush Street and in west Street Thirty Meters Military Street (currently: Kargar). Intersections were designed at a right angle. Streets and squares turned into main transport channels and passages. And this distinguishes them from older squares and the streets, as in fact communications were pedestrians. The two streets of Shahreza (Enqelab) and Pahlavi (Vali Asr) that both were named after the governor, were the main east-west and north-south axes of the city structure. In this period (1933) Tehran was further extended with an area of 46 square kilometers, i.e. 11 times bigger than the period of Fath Ali Shah and 2.5 bigger than reign of Naser-al-din Shah, respectively. Aside from new streets, new elements of modern life that had no place until that era gradually emerged in the body of the city. During the years 1925 to 1941 Tehran Railway Station, Baghshahi Fort, Najmieh hospital, Tobacco Factory, National Garden (City Park) and Tehran University were built and established. (Madanipour, 61: 2002).

In the second Pahlavi era, with rapid urbanization, the development of new residential areas, the creation of new routes and the construction of new educational, health and cultural places, the need to build newer routes emerged. These routes were often along the first Pahlavi along routes, with the emphasis on the new development and formation to the north, west and east of the city, and covers a bit higher part of city. The first measures began since the first Pahlavi in Iran and continued in the second Pahlavi era was to establish the pattern of modern life into the country. These interventions caused mismatch to the identity of urban spaces and alienated people with urban spaces over time. Interest in recreation and outdoor excursion, pilgrimage that were mainly through walking, were the characteristics of the city. In addition markets were places of social interaction of people whom lived in a coherent context and in a sectarian thought. Continued efforts during the first Pahlavi era was to define a different identity for each streets, with the establishment of different applications in different streets. For example, in the east - west Axis of Shahreza streets and North - South Axis of Ferdowsi Street, most public buildings such as universities, hospitals, and schools were built. Laleh Zar and Istanbul streets, with the emergence of new hotels and cafes and shops were recreation centers (Madanipour, 61: 1381).

At the beginning of the 1960s with the aggravation and confrontation between the north and south of Tehran, gradually attractions of the city center was reduced. And the tendency to leave the area by families who prefer new villas in the north of the city was formed. Changing the location of government building from the Marble Palace to Niavaran fueled this trend. In contrast to the position that these areas are in relation to the geometric center of the city, the development of office and commercial applications were intensified and in the same areas, Tehran's first high rise buildings were constructed (aluminum building), thus attractions decline and business activities and workshop continually increases till the Islamic Revolution. Tehran development in the aftermath of the Second World War was very fast and out of control. Within 45 years after 1941, the population grew 6.8 times and area expanded 12 times. The growth emerged in form of development in surrounding areas and towns, which gradually merged within the urban context (ibid: 61). 
The study of land use in the studies indicates that the relative contribution of residential land use in the surrounding context is relatively lower in this area. And large-scale urban and megalopolis use such as universities, cultural centers and art (Vahdat Hall, City Theater ...), stadiums and hospitals had been allocated a larger share. According to the land use map of the area, a large part of Enqelab St. is dedicated to multi-users activities. These include buildings with stores in the first floors and administrative offices on top. And on the southern edge axis, especially between Jamalzadeh Street to the College Crossroad the distribution is more. The highest concentration of non-residential types of users is on the edge of Enqelab St.

Groups of commercial and administrative use in parts of the Enqelab axis, followed the establishment of Tehran University have created special performance. The most important of these performances is the route of bookstores and the publications from Enqelab Square to Vesal Intersection. Bookstores and also retail units and CDs sellers, stationery stores as well as publishing houses infiltrated at the southern edge of Enqelab street along the north-south axis, such as Fakhr Razi street, University street, Aburayhan street and an area have created an area of the publication and books supply. Suits stores at the southern edge of the other side of Amir Kabir University is of special performance with a long history. The most important characteristics of land use in this area is performance. Some examples are: the accumulation of educational land uses (Tehran University, Amir Kabir University, Tehran Azad University, University of Arts, University of Religions, and University of Applied Science etc.) cultural land uses (City Theater, etc.) which have national level performance. Cinemas and galleries and museums as other cultural facilities are located in this area, too.
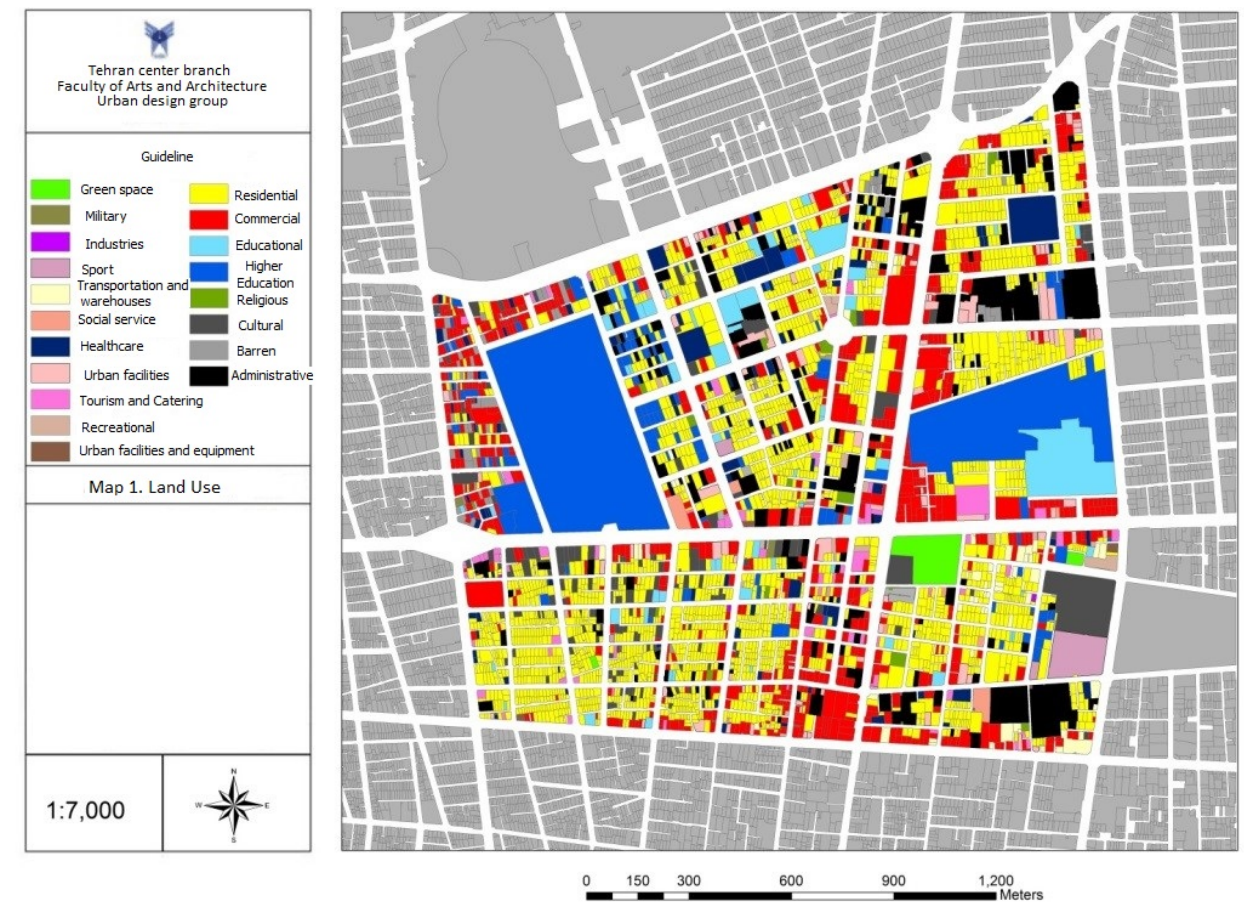

Map 1. Land Use

Enqelab Street is center of Iran and Tehran's important areas. Establishment of Tehran University in 1934 was the most unique influential attempt in the physical (factor effective in other activities of Enqelab Street) and semantic dimensions of (effective civil and social events of Tehran University) Enqelab Street. In addition, the city theater in Tehran is as the second unique activity in the presence of two 
classes of citizens and artists. The second front influential activities are Rudaki Hall, Alborz high school, Azad University of art and architecture, Tehran University of Art and Amir Kabir University.
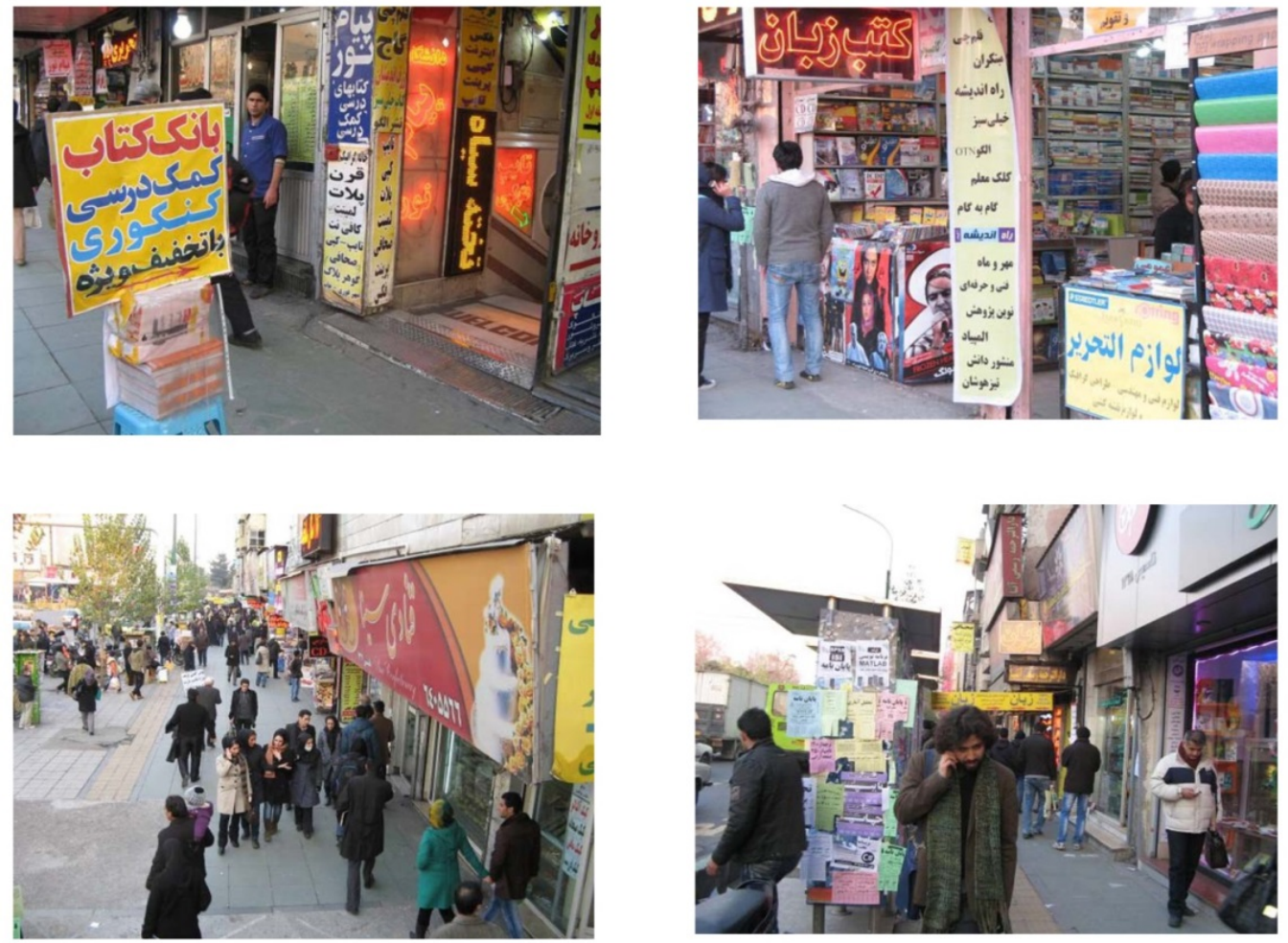

Fig 2. Bookstores route

Based on what was stated, public life in Enqelab Street owe to main and influential activities of Enqelab Street such as Tehran University, bookstores, City Theater and so on. With unique features that can be seen on Enqelab Street compared to other streets. Its place is beyond a public space. And this difference is due to current public life since its formation. Formation of uses depends was formed in accordance with Tehran University. (Tehran University is a symbol of modern cultural renaissance) as after the establishment of the Tehran University, educational institutions such as Azad university of art and architecture, Tehran University of Art and Amir Kabir University and cultural institutions such as cinemas, theaters, bookstores and cafes are formed. The locations of mentioned items are presented on the map below. And due to the proximity of numerous restaurants we refused to write the names on the map. Cafes' location can be seen in the following table.

Table 2. Cafes' Location

\begin{tabular}{|l|l|}
\hline $\begin{array}{l}\text { Name of the } \\
\text { Cafe }\end{array}$ & Address \\
\hline Godo Cafe & Enqelab Street, Vali Asr intersection \\
\hline Sepidgah Cafe & Enqelab Street, next to Sepideh cinema \\
\hline Verta Cafe & Enqelab Street, next to Sepideh cinema \\
\hline College Cafe & Enqelab Street, near the eastern side of Daneshjoo Park \\
\hline
\end{tabular}




\begin{tabular}{|l|l|}
\hline Max Cafe & Enqelab Street, opposite the Daneshjoo Park \\
\hline Honar Cafe & Enqelab Street, not far from the Vesal, Osku Alley \\
\hline Give Cafe & Palestinian street, Nayebi Jerusalem \\
\hline Lorca Cafe & Enqelab Street, Bozorgmehr St. \\
\hline $\begin{array}{l}\text { Coffee Qajari } \\
\text { Cafe }\end{array}$ & $\begin{array}{l}\text { Enqelab Street, not far from the Vali Asr intersection, Mozaffari Street, } \\
\text { Khajeh Nasir alley }\end{array}$ \\
\hline Gandom Cafe & Street, revolution, Vali Asr intersection, Passion Alley \\
\hline Nazdik Cafe & Enqelab Street, East side of Tehran University, Qods street \\
\hline Moon Cafe & Enqelab Street, beginning of Vesal Shirazi \\
\hline Inja Cafe & Enqelab Street, Abu Reyhan Street \\
\hline Ronas Cafe & Enqelab Street, South Palestine \\
\hline Selfie Cafe & Enqelab Street, Vali Asr intersection, Passion Alley \\
\hline
\end{tabular}

\section{DISCUSSION AND FINDINGS}

By studying the concepts and theoretical foundations, social exclusion factors include: access to space (visual access, physical access, and social access), access to activities and ownership. The results are as follows in accordance to obtained criteria and interviews analysis:

1. Although Tehran University in terms of law has governmental ownership, and there is no legal impediment so that the university be a public domain, it has been enclosed by fences. And lack of access to space through lack of physical accessibility exists for social groups except Tehran University students and staff. It is followed by control of its activities and lack of access to the space activity through ownership and decision on the use of space has led to the exclusion of other segments of society. This is also true for Amir Kabir University. Tehran Art University and university of art and architecture also have visual limitations in terms of access.

2. Some cafes in Enqelab Street such as Max, Godo, College, Sepidgah and Verta ... have visual and physical access through social and sometimes symbolic boundaries and symbolic ownership of the student and artists led to lack of access to other social individuals. Thus, access to space is only for students and interested persons in the art and sometimes more specific groups of students. In fact, activities in space is inviting for them, so that other people are experiencing social-spatial exclusion.

3. In Daneshjoo park, despite visual and physical access, social boundaries due to of the presence of transvestites and drug-related sales and symbolic ownership of these groups leads lack of social access; followed by the lack of inviting for others, so that other people are experiencing social exclusion. And also transvestites around the city theater create social boundaries after sunset which leads to exclusion.

4- In other spaces of Enqelab Street, despite the visual and physical and social access for all people, there is no access to activities for all. Because the activities in the space is not inviting for all. The continuous presence of these people lead to a situation that the symbolic ownership is attributed to them. For example, in the theater area: during the day students and in afternoon artists and art enthusiasts attend and sit down to dialogue or to see the theater. So that these activities is not inviting to others. Another 
example is bookstores that despite no lack of physical and social access people show little interest in watching showcases, except when it is compulsory for them to participate on that activity. Because the activities such as vendors (reduces the width of the sidewalk), distributing propaganda leaflets prevent invitation. And most of people walk on these routes since they have in front of Tehran University, despite no boundary, and only Tehran University students work in outer space. This activity is not inviting to others. This lack of access to the activity leads to social-spatial exclusion for other people.

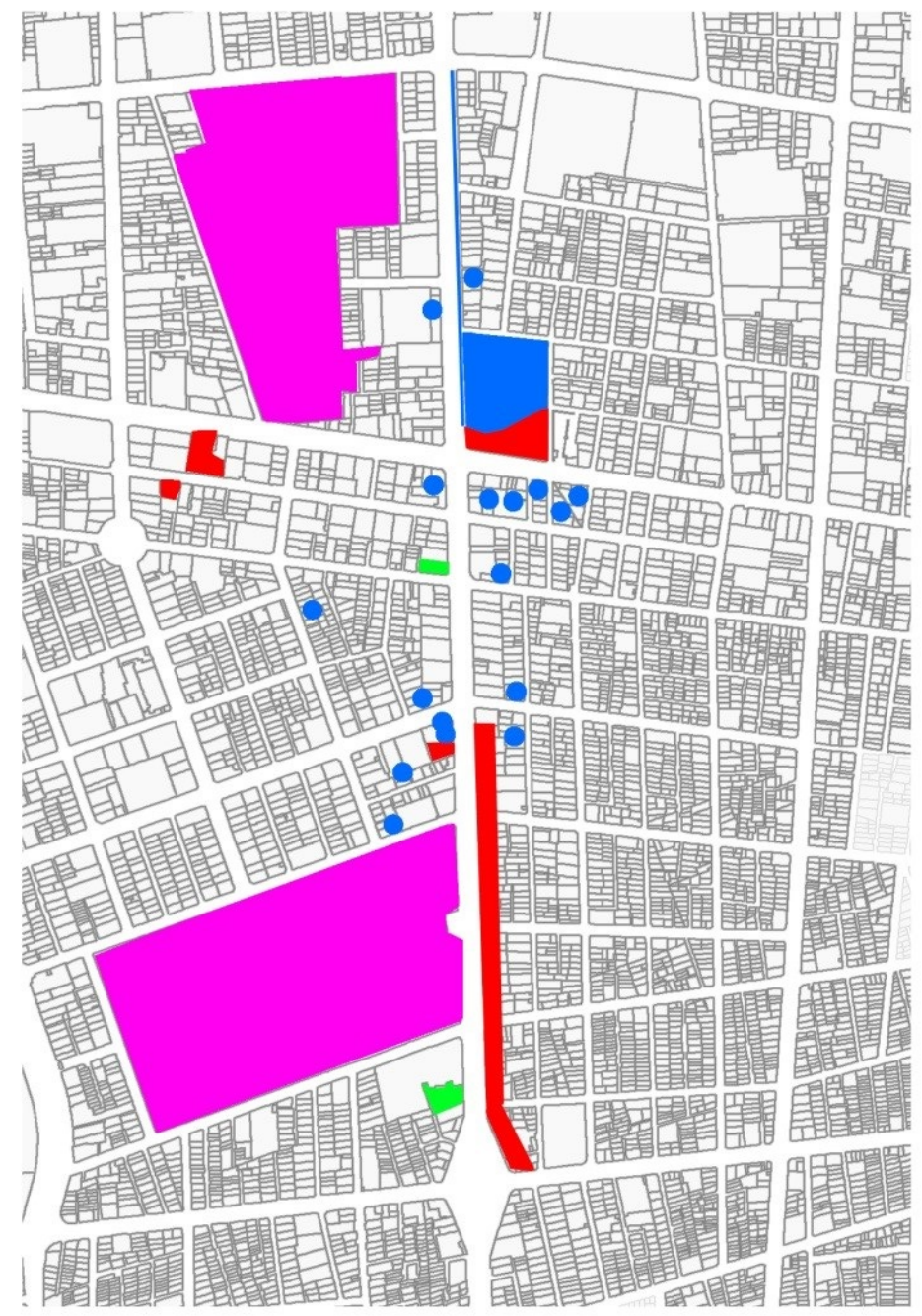

$\stackrel{9}{\underline{4}}$

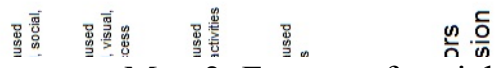
Map 2. Factors of social-spatial exclusion 


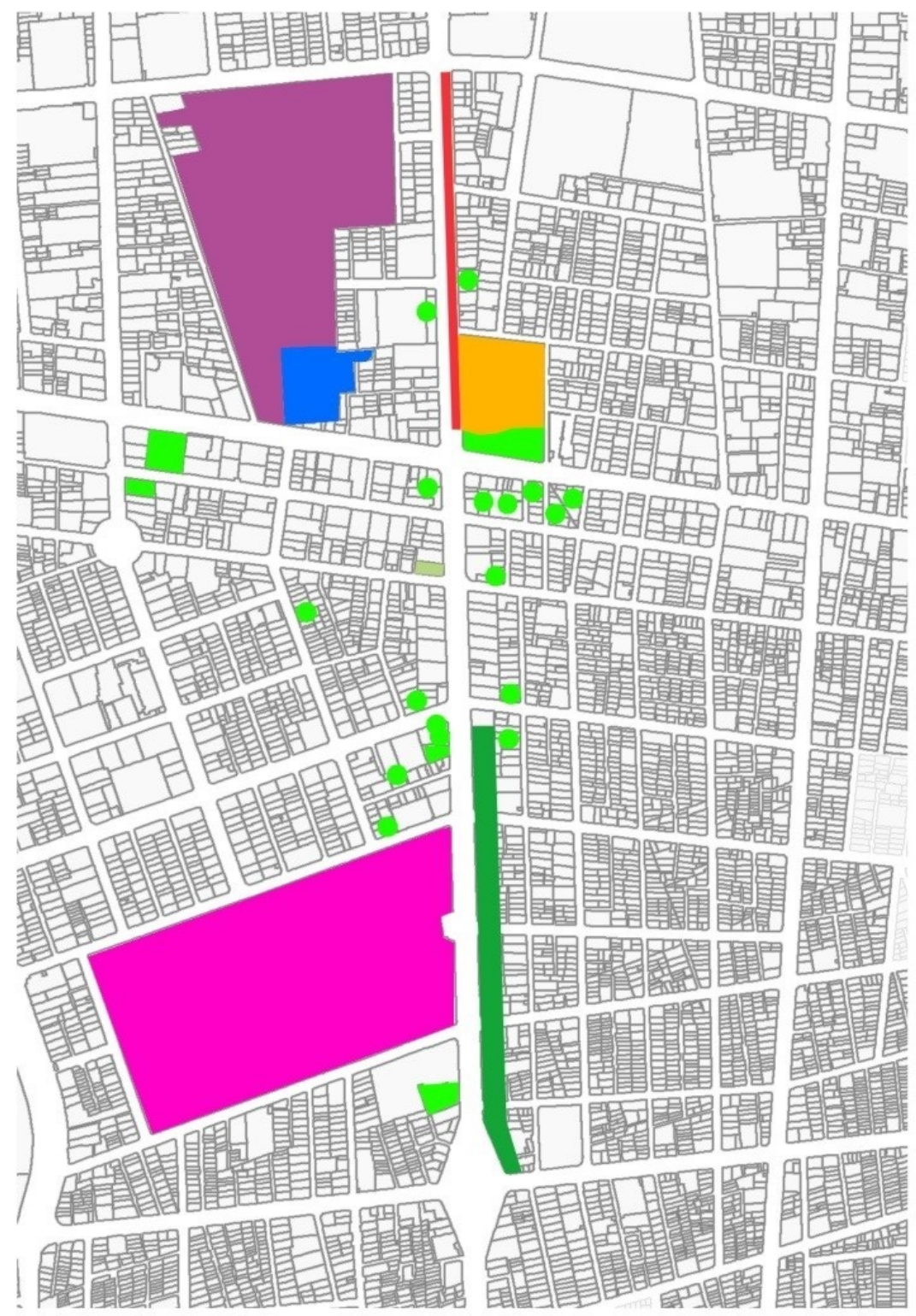

果:

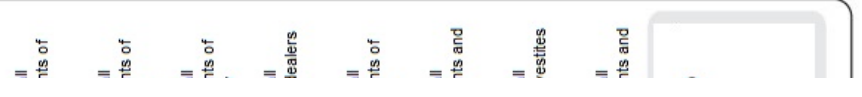

Submit Date: 05.06.2016, Acceptance Date: 23.07.2016, DOI NO: 10.7456/1060AGSE/069

Copyright (C) The Turkish Online Journal of Design, Art and Communication 
Map 3. Deprived and Excluded Groups

In response to the question: "How and by which means, one can reduce social-spatial exclusion in Enqelab Street in Tehran", Results in Table 3 are provided.

Table 3. Suggestions to Reduce Social Exclusion

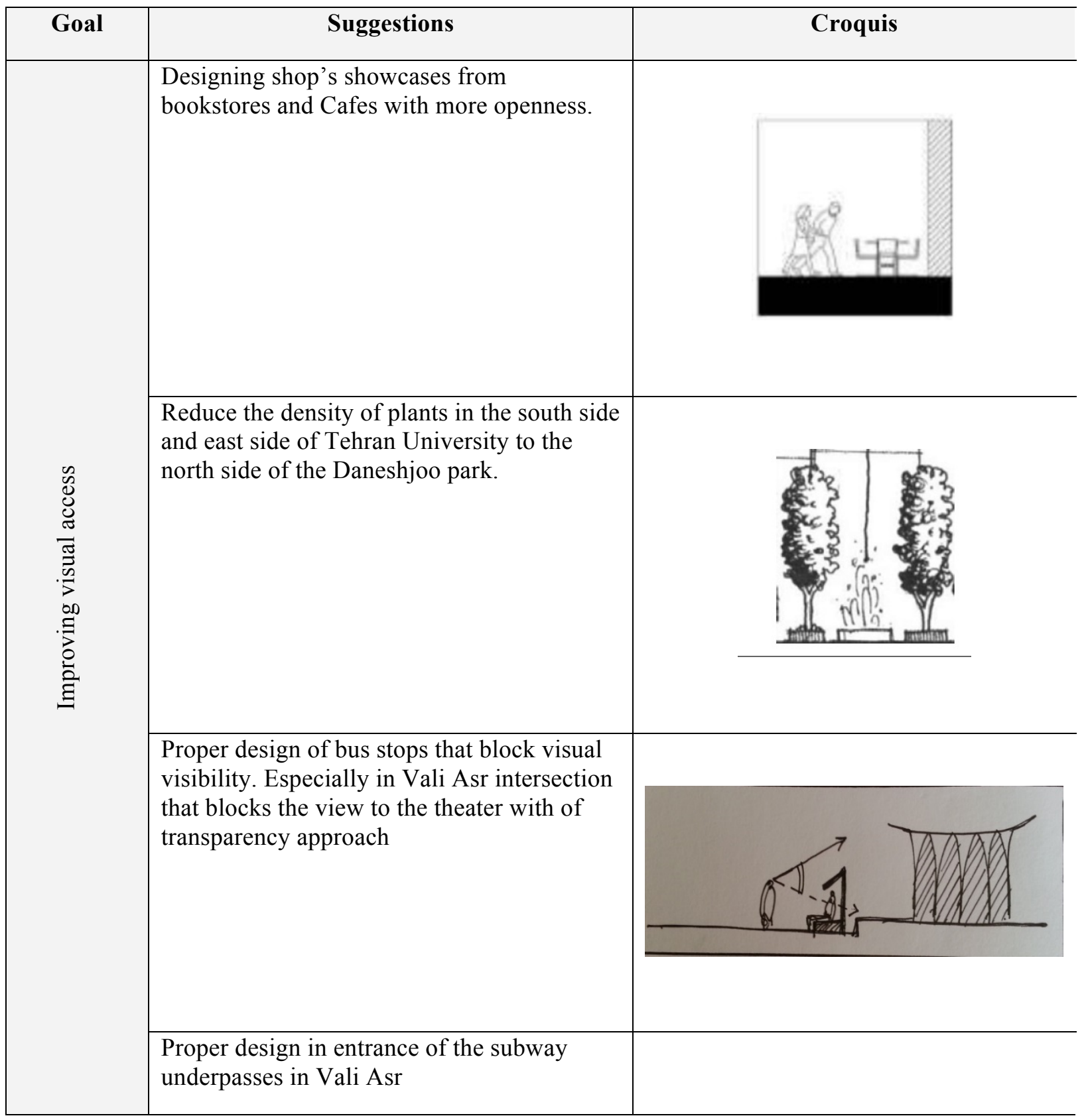



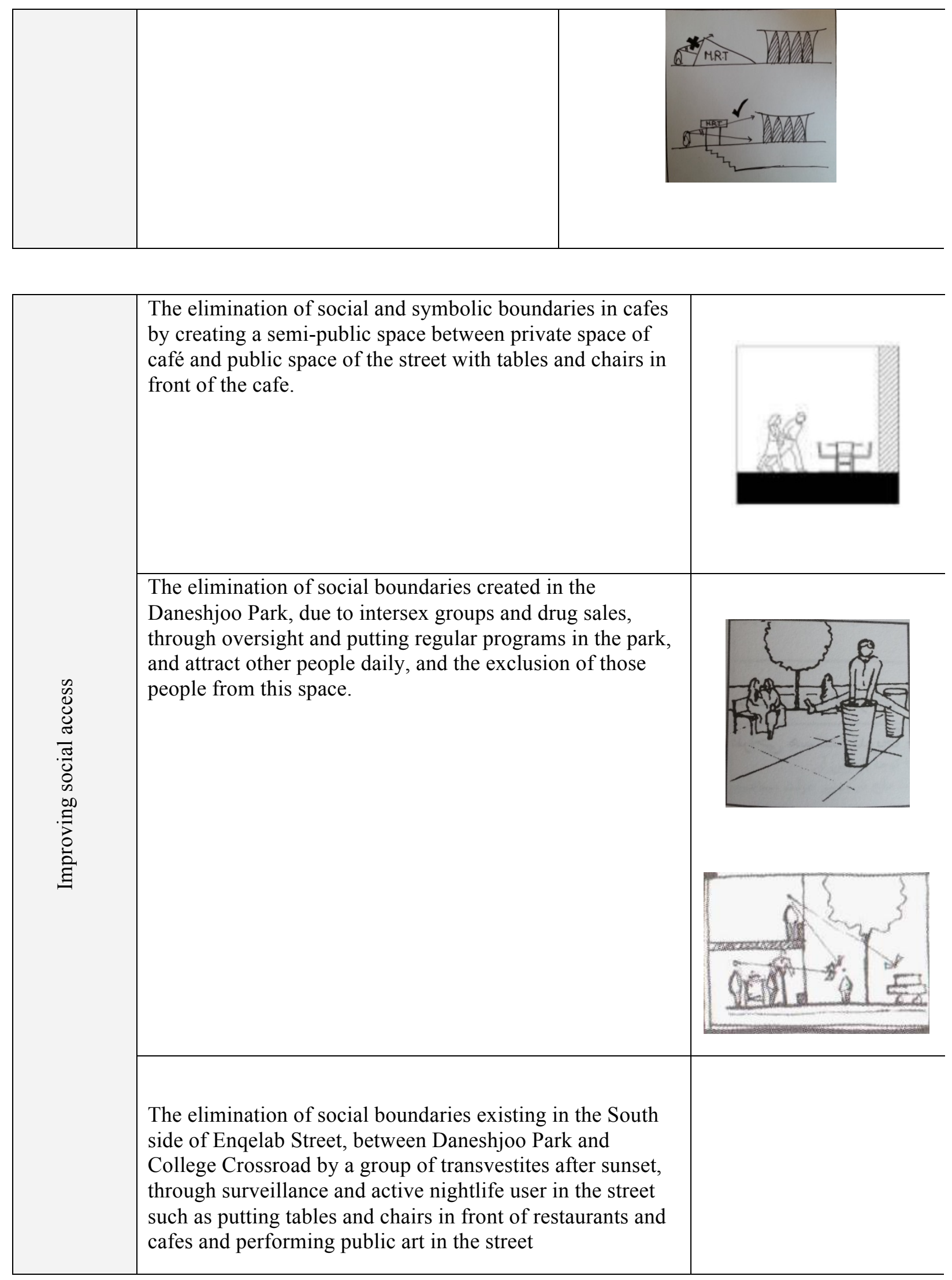


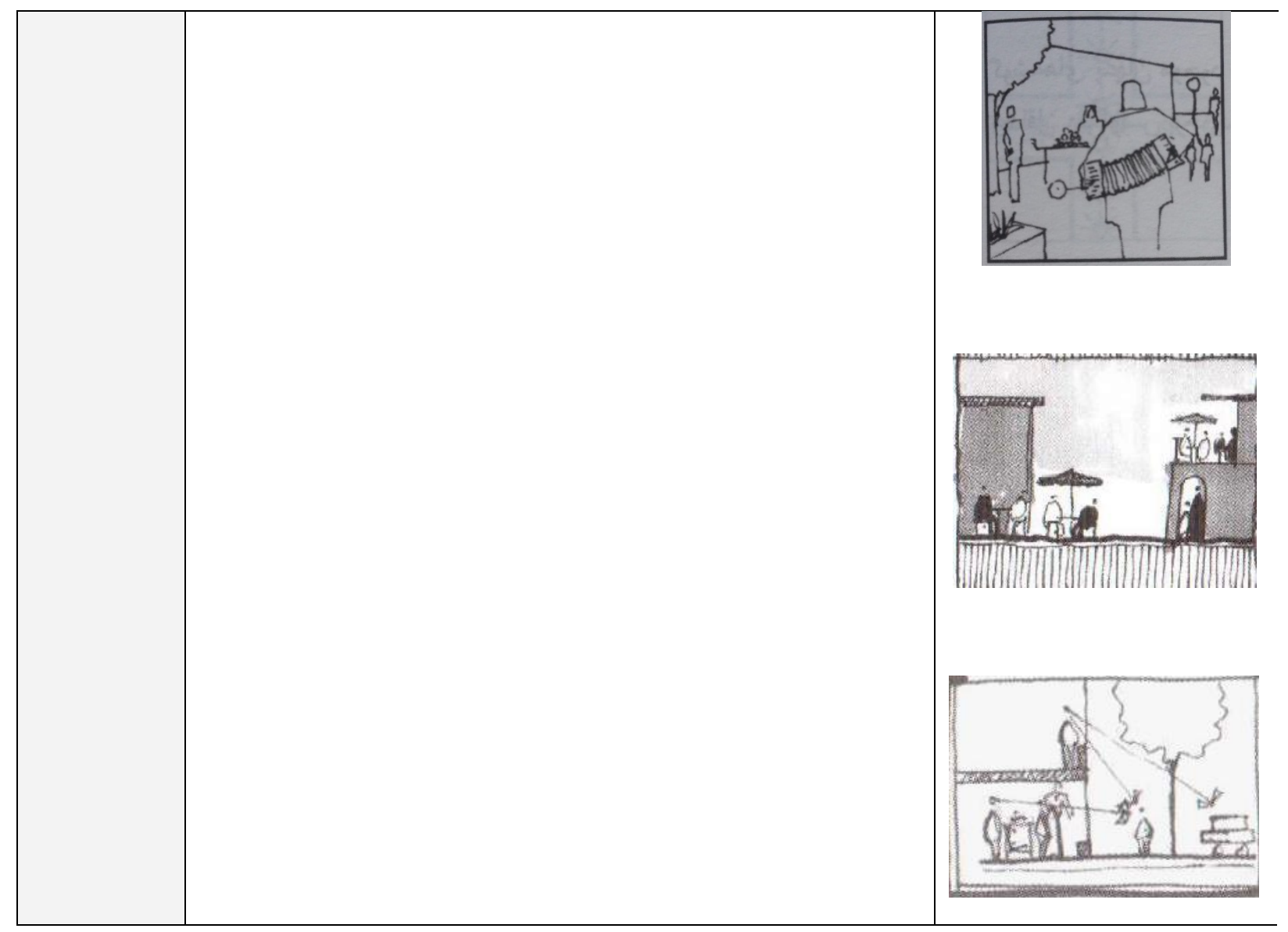

\begin{tabular}{|l|l|}
\hline & $\begin{array}{l}\text { Good design of Tehran University, Amir Kabir } \\
\text { University, and Tehran art university edges by } \\
\text { creating a semi-public space, between the public } \\
\text { space of the street and the interior of the } \\
\text { university. }\end{array}$ \\
\cline { 2 - 3 } & $\begin{array}{l}\text { The lack of using of real ownership rights for } \\
\text { privatization by using physical barriers to the } \\
\text { Tehran University. }\end{array}$ \\
&
\end{tabular}




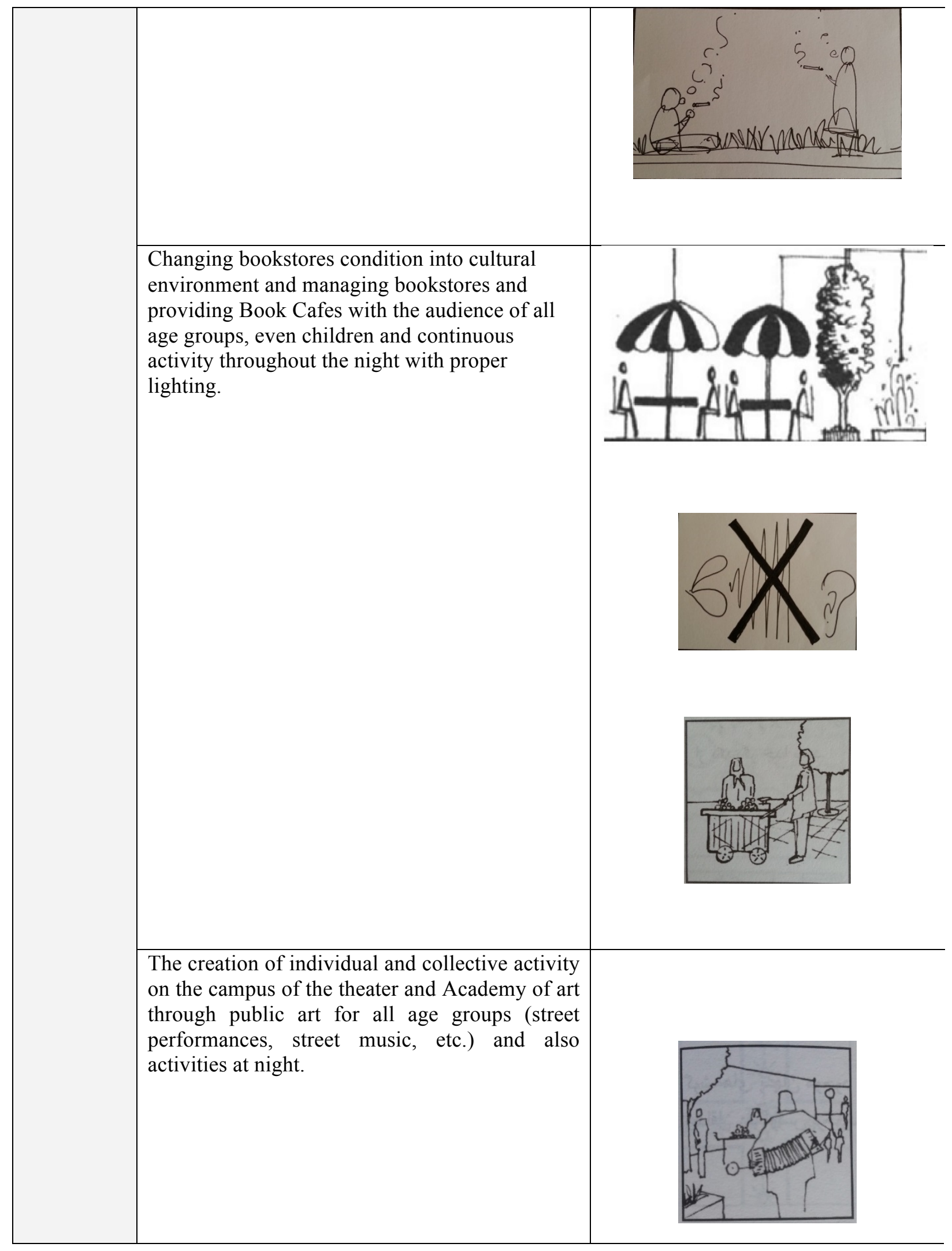




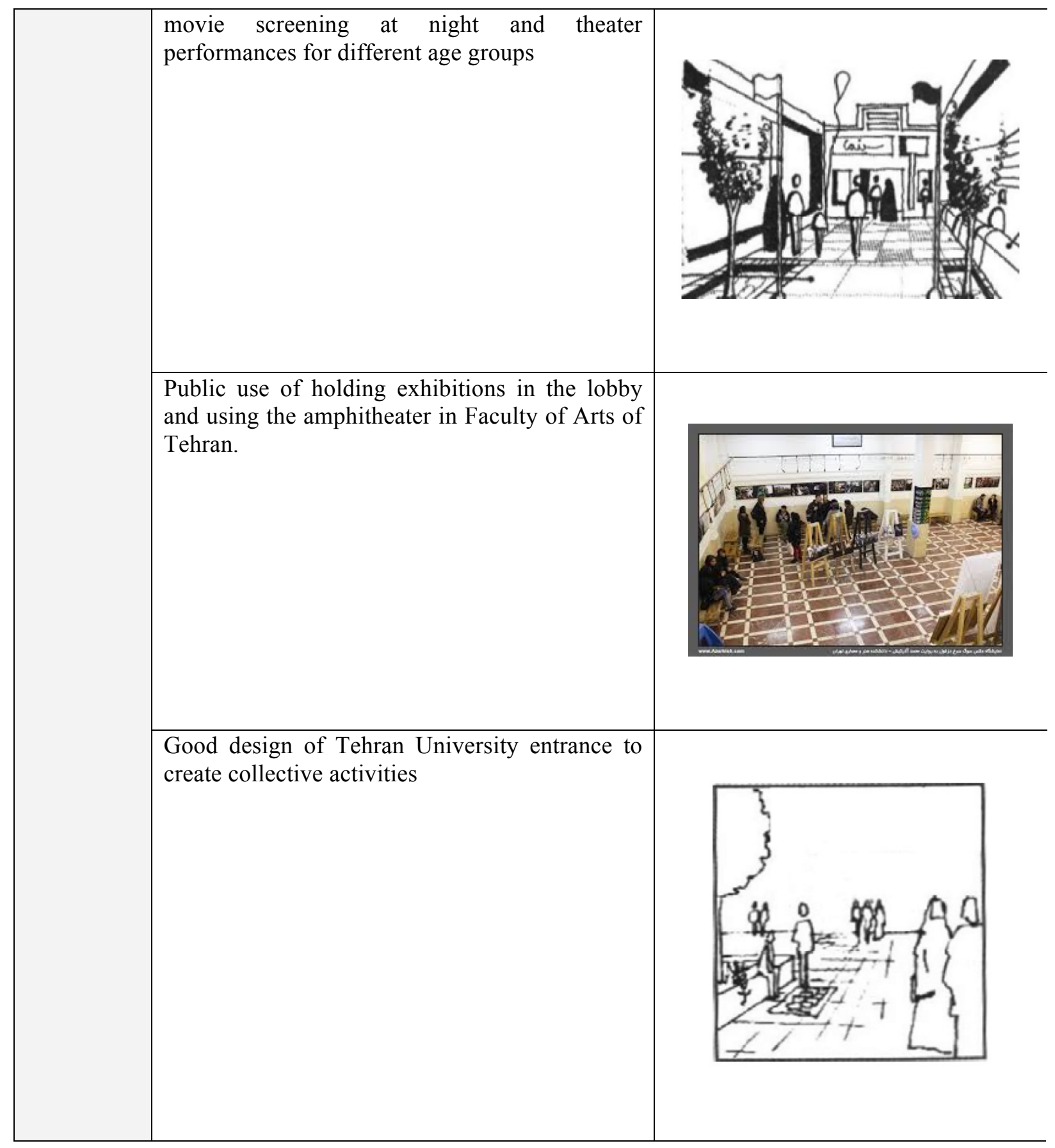



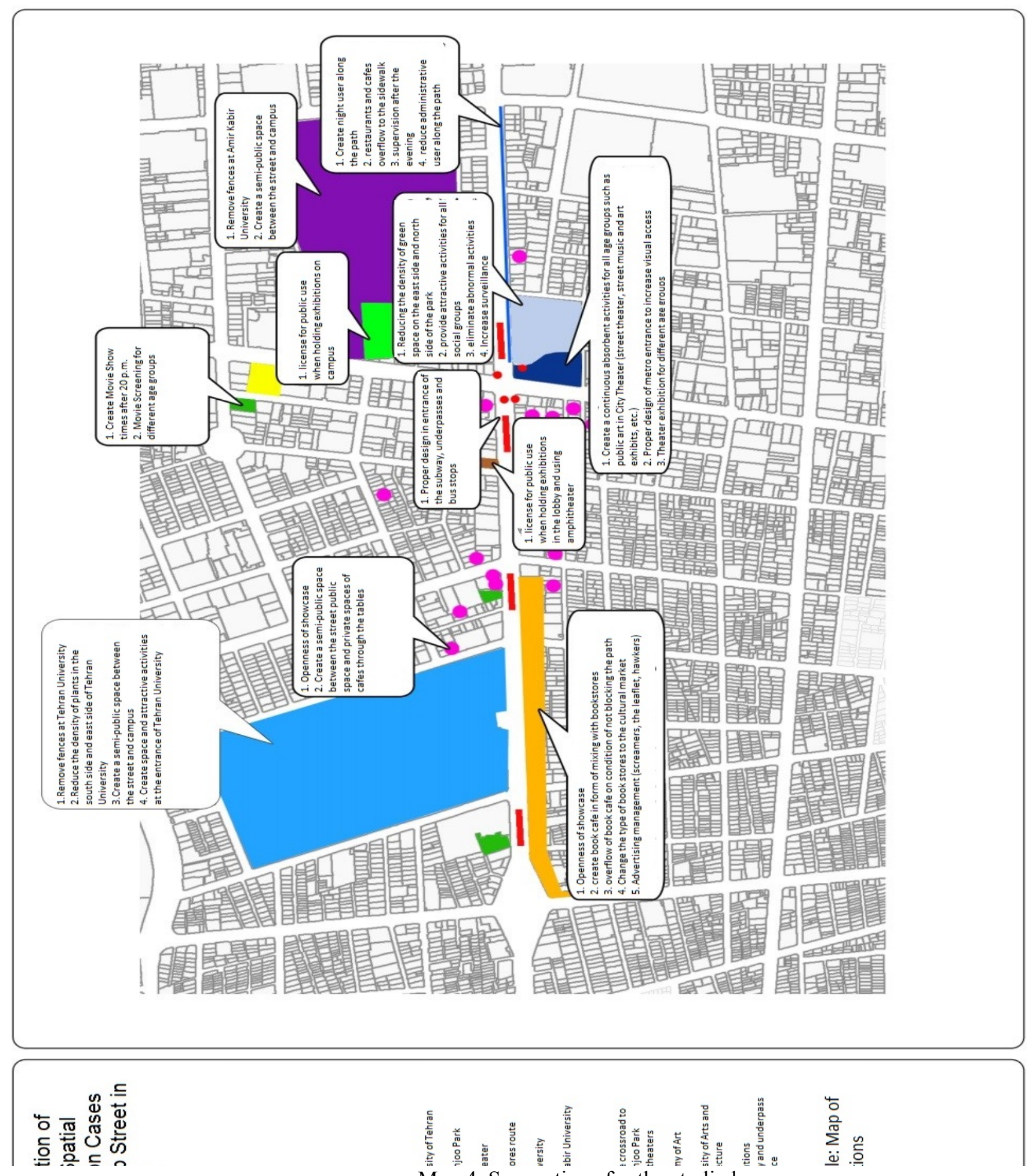

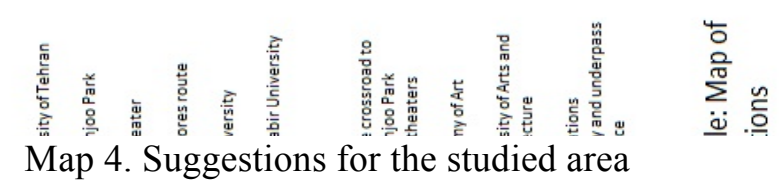




\section{CONCLUSION}

In fact, when we lack physical access, social-spatial exclusion has higher domination, because lack of physical access leads to lack of social access and access to activities for others; as the owner often decides on prohibiting visual access of the space. Another types of exclusion that is caused by physical access is when a person despite his interest to attend in a space, bans himself from the space due to the presence of social boundaries (intensity of deprivation in the social boundaries that their pattern is negative increases.), which is significantly lower than the first group. The last type when no social and physical boundaries exists, but the activities in space are not inviting for those who do not like it. In fact, despite the potential, space is not inviting for other people.

\section{REFERENCES}

Hariri, Najla (2006), "Qualitative research principles and methods", First Edition, Tehran Azad University, Science and Research Publication

Rezvani, Navid, (2014), "A New Look at the factors affecting access", the study of human geography, N. 1, Spring.

Simmel, Georg, (1993), "Metropolice and mental health" Abazari, Yosef, social sciences, third number, Tehran University, Spring

Carmona, Matthew (2004) "public places of urban spaces: different aspects of Urban Design", translated by Zahra Ahari, Fariba Gharayi, Mahshid Shokuhi, Esmail Salehi, Abolfazl Tavakoli, University of Art, Tehran.

Carmona, Matthew (2002) public places, urban spaces: different aspects of urban design, translated by Zahra Ahari, Fariba Gharayi, Mahshid Shokuhi, Esmail Salehi, Abolfazl Tavakoli, University of Art, Tehran.

Madanipour, Ali. (2002), "Tehran emergence of a Metropolis", translation by Zaravand, Hamid, processing and urban planning, Tehran.

Madanipour, Ali (2008), "Designing urban space: Attitude toward social and spatial processes", translation by Mortezai, Farhad., publication by urban planning, Tehran.

Madanipour, Ali (2010), "public and private spaces of the city", translated by Farshad Norian, Nashr Ney publication, Tehran.

Altman,Irwin\& H.Zube,Ervin, "public places and spaces".

Levitas Ruth, et al, "The multi-dimensional Analysis of Social Exclusion", Bristol Institute for public Affairs,Jan 2007

Hirsch, Andrew, Garland, David, Wakefield, Alison (2000) "Ethical and Social Perspectives on Situational Crime Prevention", Oxford-Portland, Oregon

M.Philips\&Derek S.Pugh(2005), "HOW TO GET A PhD A handbook for students and their supervisors",Fourth Edition revised and uptodated 